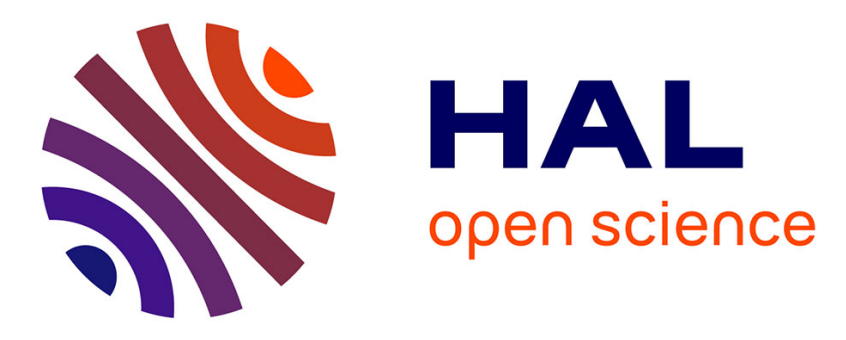

\title{
Spatial variation of wood density, stiffness and microfibril angle along Eucalyptus trunks grown under contrasting growth conditions
}

Paulo Ricardo Gherardi Hein, Gilles Chaix, Bruno Clair, Loïc Brancheriau, Joseph Gril

\section{To cite this version:}

Paulo Ricardo Gherardi Hein, Gilles Chaix, Bruno Clair, Loïc Brancheriau, Joseph Gril. Spatial variation of wood density, stiffness and microfibril angle along Eucalyptus trunks grown under contrasting growth conditions. Trees - Structure and Function, 2016, 30 (3), pp.871-882. 10.1007/s00468-0151327-8. hal-01451896

\section{HAL Id: hal-01451896 \\ https://hal.science/hal-01451896}

Submitted on 1 Feb 2017

HAL is a multi-disciplinary open access archive for the deposit and dissemination of scientific research documents, whether they are published or not. The documents may come from teaching and research institutions in France or abroad, or from public or private research centers.
L'archive ouverte pluridisciplinaire HAL, est destinée au dépôt et à la diffusion de documents scientifiques de niveau recherche, publiés ou non, émanant des établissements d'enseignement et de recherche français ou étrangers, des laboratoires publics ou privés. 
Hein PRG, Chaix G, Brancheriau L, Clair B and Gril J (2016) Spatial variation of wood density, stiffness and microfibril angle along Eucalyptus trunks grown under contrasting growth conditions. Trees (Berlin. Print) 30(3): 871-882

DOI: $10.1007 / \mathrm{s} 00468-015-1327-8$

Spatial variation of wood density, stiffness and microfibril angle along Eucalyptus trunks grown under contrasting growth conditions

Paulo Ricardo Gherardi HEIN*

Departamento de Ciências Florestais, DCF

Universidade Federal de Lavras

CEP: 37200-000 Lavras - MG, Brasil

e-mail: paulo.hein@dcf.ufla.br

*corresponding author

Gilles CHAIX

CIRAD UMR AGAP

ESALQ-USP, Piracicaba, Brazil

\section{Bruno CLAIR}

Laboratoire "Sciences des Bois de Guyane"

UMR "Ecologie des Forêts de Guyane" (EcoFoG)

Campus Agronomique, BP 701

97387 Kourou, French Guiana

\section{LOÏc BRANCHERIAU}

CIRAD - PERSYST Department

Performances des systèmes de production et de transformation tropicaux

UPR 114 "Biomasse, bois, énergie, bio-produits"

73 Rue Jean François Breton TA B114/16

34398 Montpellier Cedex 5

\section{Joseph GRIL}

Laboratoire de Mécanique et Génie Civil, CNRS

Universite Montpellier 2 Place E. Bataillon, cc 048

34095 Montpellier, Cedex 5, France

\section{ACKNOWLEDGMENTS}

The author expresses your special thanks to the CENIBRA NIPO-BRASILEIRA for providing trees; to the Department of Wood Science and Technology of the Universidade Federal de Lavras (UFLA, Brazil) for supporting the experimental work and to the Centre de Cooperation Internationale en Recherche Agronomique pour le Development (UMR AGAP and UR BIOWOOEB of CIRAD, Montpellier, France) for laboratory facilities. The authors would like 
to thank Arie van der Lee from Institut Européen des Membranes, CNRS and University of Montpellier for assistance for X-ray diffraction measurements. This study was funded by CENIBRA (Celulose Nipo-Brasileira), CNPq (Conselho Nacional de Desenvolvimento Científico e Tecnológico, Brazil) and CIRAD (UR BIOWOOEB). P.R.G. Hein was supported by CNPq grants (process no. 200970/2008-9).

The authors declare that they have no conflict of interest.

Spatial variation of wood density, stiffness and microfibril angle along Eucalyptus trunks grown under contrasting growth conditions

\begin{abstract}
Few studies have investigated the influence of environmental conditions on the within-tree variation in Eucalyptus wood traits. The genotype and environment effects and their interactions influence the wood properties. Their evaluations are crucial to estimate the genotype values and to select with efficiency. Thus, the aim of this study was to better understand the effect of ground slope and wind speed on the spatial variation of basic density ( $\rho$ ), stiffness (MOE) and microfibril angle (MFA) of Eucalyptus wood. Wood discs cut along the trunk were sampled from 150 six-year-old Eucalyptus grandis x E. urophylla hybrids growing in 3 contrasting growing conditions influenced by ground slope and wind regime. Near Infrared (NIR) calibrations previously developed for $\rho$, MOE and MFA were used to predict in our discs. 2-D plots presenting the spatial variation of predicted wood traits were compared. The higher the ground slope, the greater the magnitude of radial variation in $\rho$, principally in the medium zone of the trunk. The spatial variation of wood stiffness seems to be sensitive to two environmental conditions. The MFA radial decreases were more pronounced where the wind speed was higher. At the base and top of the trees, however, there was no significant effect of growing conditions on the radial variation of the wood properties considered here.
\end{abstract}

Keywords: terrain slope, wind speed, modulus of elasticity, density, MFA, NIR spectroscopy, Environmental control, wood quality

Key message: Sloped terrains tends to produce trees with higher radial variation in wood density while at high wind speeds, the wood tends to present higher stiffness and lower MFA in Eucalyptus. 


\section{INTRODUCTION}

As a fast-growing and short-rotation source of wood, the Eucalyptus plantation is the basis for several industries, such as pulp and paper, sawn and engineered products, and - particularly in Brazil - charcoal in "green steel" industries. Although most of the biomass from breeding programs presents an optimal performance for pulp and energy purposes, limited information is available concerning their performance in the timber industry (Lima et al. 1999).

Eucalyptus trunks can present large spatial variation in terms of wood quality due to environmental and genetic factors (Raymond 2002). Numerous studies have reported similar patterns of radial (Chafe 1986, Oliveira and Silva, 2003) or longitudinal variation for wood density (Quilhó and Pereira 2001, Alzate et al. 2005), wood stiffness (Cruz et al. 2003) and MFA (Evans et al. 2000; Lima et al. 2004; Hein and Brancheriau 2011) in the genus Eucalyptus. In short, patterns in pith to bark variability of wood traits from forest plantations are known: wood density and stiffness generally increases while MFA decreases towards the bark (Kollmann and Côté 1968), although reports on the longitudinal variations of these traits for this hardwood are rare. As wood with high density $(\rho)$ and modulus of elasticity (MOE) and low microfibril angle (MFA) normally present higher grades for structural uses (Walker and Butterfield 1995), these trends become more suitable for sawn timber production as trees become older.

According to Zobel (1992), anything that can change the growth pattern of a tree may result in wood variation and the response of the tree and its wood properties from this change cannot be easily predicted. That is why most researches on wood variation caused by different growing condition are contrasting for many species. For instance, Guilley et al. (2004) have shown that wood density of Quercus hardly changed with changing environment (five French regions crossed with three site qualities) and type of silviculture (coppice-with-standards and high forest) while Zhang et al. (2011) reported that the key environmental factor explaining the spatial patterns of wood traits of 618 tree species growing in China was the mean annual rainfall.

Few studies have investigated the environmental effects on the within-tree variation in Eucalyptus wood traits. Downes et al. (2012) have investigated the variability of pulp yield and cellulose content within Eucalyptus globulus trunks growing in three contrasting sites. They pointed out that pulp yield and cellulose content were higher in the more productive sites, the wetter ones. Moreover, the trees in these sites exhibited more significant pith-to-bark increases in pulp yield than those in the driest site (less productive). On the other hand, Miranda et al. (2001) investigated 9-year-old Eucalyptus globulus from 37 provenances in three sites, reporting that sites did not influence wood density variation. To sum up the general trends in Eucalyptus, Gonçalves et al. (2004) presented a complete review based on a majority of the studies on Eucalyptus describing how silvicultural practices affect the productivity and wood quality. However, information concerning the extent to which specific environmental factors affect wood formation and its properties are limited and contrasting.

To our knowledge, there is no information reporting to what extent the ground slope and the wind speed influence spatial variations in Eucalyptus wood, especially in juvenile wood. Thus, the aim of this study was to better understand the effect of ground slope and wind speed on the spatial variation of $\rho$, E and MFA of Eucalyptus wood. The strategy here was to use previous NIR calibration models for prediction of $\rho$, MOE and MFA from spectra measured at different 
radial and longitudinal positions of Eucalyptus trunks. We studied 6 years old trees because the rotation cycle of Eucalyptus is 6 years for pulp and paper production while 4-5 year-old trees are used for bioenergy purposes in Brazil.

\section{MATERIAL AND METHODS}

\section{Vegetal material and sampling}

One-hundred fifty (150) 6 year-old Eucalyptus grandis x E.urophylla hybrids growing in three contrasting clonal tests from the Cenibra Company established in Minas Gerais State in Brazil were investigated in this study. Ten (10) hybrids coming from three clonally replicated trials established in contrasting site were investigated. Five individuals per clone were sampled in each clonal test, totalizing 150 trees (10 clones x 3 sites x 5 individuals). Trees were selected among those upright, healthy, without fork. Sites labeled as 302 and 303 present similar weather conditions, but the terrain slope was very contrasting. The location of these two clonal tests is close. The Clonal test 301 is around 200 kilometers distant from others and weather conditions are different, especially the wind speed. According to the classification of Köppen the climate type of the sites is Tropical savanna. The trees were planted in a randomized block design with planting density of 1,667 trees/ha ( $3 \mathrm{~m} \times 2 \mathrm{~m}$ spacing). Trees were planted in 2003 and harvested 72 months later. Figure 1 shows the difference in ground slope between clonal tests while Table 1 describes the main environmental differences between the clonal tests (slope from 0 to $40^{\circ}$, and mean wind speed from 0.9 to $3.2 \mathrm{~m} / \mathrm{s}$ ) and presents the mean values concerning tree growth (mean height between 20.4 to $23.6 \mathrm{~m}$ and mean circumference at breast height $(\mathrm{CBH})$ from 57.4 to $67.3 \mathrm{~cm})$. Possibly there are several factors influencing the growing conditions (such as soil qualities for example), but here we considered only the slope of the terrain and the wind speed as the main contrasting factors.

Table 1 and Figure 1

The first $\log$ (from the base to 2.4 meters) and five wood discs (thickness: $30 \mathrm{~mm}$ ) were cut at $0 \%$ (around $10 \mathrm{~cm}$ from the soil), $25 \%, 50 \%, 75 \%$ and $100 \%$ of the commercial height from each tree (Figure 1-A). The total sampling was composed of 150 logs and 750 discs.

\section{Wood characterization}

Resonance sonic tests were performed to determine MOE in 225 clean specimens cut from central boards of the Eucalyptus logs, according to the description reported in Hein et al. (2010a). After the resonance tests, small wood samples were removed from the clearwood specimens for determining wood density $(\rho)$ by the immersion method according to ASTM D2395 procedure (ASTM 2002) and radial sections (thickness: $2 \mathrm{~mm}$ ) were also cut from the specimens for estimating MFA using X-ray diffraction patterns as described in Hein and Brancheriau (2011).

For the resonance tests the specimens were submitted to flexural vibration analyses as described in Brancheriau and Baillères (2002) and in Hein et al. (2012). The first four modes of vibration were used for estimating the dynamic transversal modulus of elasticity (MOE) of wood according to the Timoshenko (1921) motion equation. The analysis of the spectral signal, the selection of the peaks of the natural frequency of vibration of the wood samples and the $\mathrm{E}$ estimates were performed using the software BING ${ }^{\circledR}$ (CIRAD, Montpellier, France, version 9.1.3). 
The MFA estimates were based on the X-ray diffraction patterns collected on a diffractometer (Xcalibur-I, Oxford Instruments, USA) with $\mathrm{CuK} \alpha$ radiation. An X-ray diffraction profile was recorded from 225 radial sections. The formula of Yamamoto et al. (1993) was applied in order to estimate the MFA based on the X-ray diffraction pattern.

The repeatability errors of the MOE and MFA measurements were estimated as 5\% and 3\%, respectively. The detailed procedures for sample preparation and measurements of $\rho$ and MFA are described in Hein et al. (2010) while those for the elastic modulus are given in Hein et al. (2012).

\section{NIR spectroscopy}

The same Bruker spectrophotometer (model Vector 22/N, Bruker Optik GmbH, Ettlingen, Germany) was used in the diffuse reflectance mode for the spectrum measurement. This Fourier transform spectrometer is designed for reflectance analysis of solids using an integrating sphere which measures the diffuse reflected light. This integrating sphere $\left(150 \mathrm{~mm}^{2} \mathrm{spot}\right)$ collects light from all angles; thus, the effects of wood texture and other non-homogeneities are minimized. It is also practical that the sphere is "upward looking", with a window on top of the sphere. The diameter of the measured area is $10 \mathrm{~mm}$. A sintered gold standard was used as background. Spectral analysis was performed from 9000 to $4000 \mathrm{~cm}^{-1}$ range at $8 \mathrm{~cm}^{-1}$ resolution. Each NIR spectrum was obtained by means of 16 scans; means were calculated and compared to the gold standard to obtain the NIR spectrum of the sample.

NIR spectra were recorded on the clearwood specimens, on the cubic samples and on the longitudinal-radial sections for calibrating and validating NIR-based models. Partial Least Square (PLS) Regressions were developed to correlate NIR spectra to the laboratory-determined values of $\rho, \mathrm{MOE}$ and MFA. The NIR models for predicting the modulus of elasticity are presented and discussed in Hein et al. (2010) while the calibrations for $\rho$ and MFA are reported in Hein (2012). Statistical summary of the NIR calibrations for $\rho, E$ and MFA are listed in Table 2.

Table 2

NIR spectra were recorded on local points of the radial surface of the wood discs taking into account the pith-to-cambium variation (Figure 2). The radial strip directions were defined according to the planting line, which correspond to the inclination of the terrain in the sites 301 and 302. Thus, if tension wood occurs, the radial strip will take it totally into account. These NIR spectra were taken using the same experimental settings as described in Hein et al. (2010) and Hein (2012). The NIR-based models for estimating wood traits (Table 2) were applied on the NIR spectra taken from the discs in order to estimate MOE, $\rho$ and MFA along the trunk. It is implicit in this approach that the calibration and prediction sets on which these NIR-models are based contain the whole range of variation in the wood disc samples.

Figure 2

NIR spectra were recorded in five positions on the disc from $25 \%$ of the tree height because investigating the radial variation of wood traits in more detail was one of the objectives of the project in which this study is inserted. For the other discs NIR spectra were recorded in three positions. Despite the annual rings are not evident in the trees the term inner wood refers to wood formed at the first years while outer wood represent the wood produced during the last 
year. As the tress investigated in this study present 6 years old, the heartwood formation process is just beginning.

\section{Surface plots}

2-D plots presenting the spatial variation of wood traits were developed using the Scilab software (v.5.3.1, http://www.scilab.org/). As NIR models were used to estimate wood traits on specific points along the tree trunk, data were interpolated using the cubic spline method in order to create estimates in a whole tree making it possible to build the surface graphics of the wood traits.

\section{RESULTS AND DISCUSSION}

The findings revealed a large spatial variation in wood density, stiffness and microfibril angle among the Eucalyptus trees. This spatial variation in wood trait over the trunk varies according to the growing conditions. Table 3 shows the radial variation of $\rho$, MOE and MFA along the tree height for all clones.

\section{Table 3}

\section{Spatial variation of wood density}

Pith to bark variations in wood density were more consistent than those along the trunk. Overall, the wood density strongly varied from pith to cambium at the base (increase of $137.8 \mathrm{~kg} . \mathrm{m}^{-3}$ from $460 \mathrm{~kg} \cdot \mathrm{m}^{-3}$ near pith to $600 \mathrm{~kg} \cdot \mathrm{m}^{-3}$ near cambium) while at $25 \%$ of trunk height the increase was of $131.5 \mathrm{~kg} \cdot \mathrm{m}^{-3}$ starting from $475 \mathrm{~kg} \cdot \mathrm{m}^{-3}$ (Table 3). This trait also increased radially in the upper part of the trunk, but in relatively low magnitude $\left(<100 \mathrm{~kg} \cdot \mathrm{m}^{-3}\right)$. The global increase from base to top in wood density showed by the color gradient in Figure 3 is in accordance with the findings reported by Bouvet and Baillères (1995) for Eucalyptus grandis $\mathrm{x}$ E. urophylla clones grown in the Democratic Republic of the Congo.

Figure 3

In the present study, the hypothesis is that pith-to-bark increases of the clones vary according to the environmental changes. The pith-to-bark variation in $\rho$ at $25 \%$ and $50 \%$ of the tree height was higher in trees from the site with a $40^{\circ}$ terrain slope (Table 3, values in bold). Our sampling indicates that the higher the slope of the terrain, the greater the magnitude of radial variation of wood density in the intermediate portion of the trunk. At the base and at the top of the trunk, there was no effect of the terrain slope nor wind speed. Figure 3 presents the spatial variation of the wood density inside the trunk emphasizing the radial variation of the clones in $25 \%$ of the trees height $(\mathrm{A}$ and $\mathrm{B})$.

There was a moderate genetic variation among clones, but clone 4426 seems to present the most particular behavior. Figure 3A shows that clones produce denser wood at the site where the wind speed was higher and the mean annual temperature is lower (clonal test $301,20^{\circ}$ ) both in the first (near pith, Figure 3A) and in the last (near cambium, Figure 3B) year of growth. In summary, Figure 3A and B show that the radial increase of wood density of the clones was $\sim 34 \%$ higher (Table 3 ) in the site where the slope is more inclined (clonal test $302,40^{\circ}$ ). Thus, 
variations in wood density of these clones seem to be more influenced by slope than the mean wind speed.

Many studies have shown that environments control one part of the wood variation. There is no similar study on the relationship between terrain slope/wind velocity and wood quality variation for comparing our findings. However few studies on the effect of growing conditions on wood traits variation (especially wood basic density) in Eucalyptus have been done. For instance, Thomas et al. (2007) reported a positive relationship between temperature and wood density in Eucalyptus seedlings. However, this relationship is not consistent and further studies are required.

Wimmer et al. (2008) have investigated the wood and Kraft pulp properties of Eucalyptus globulus (eight year-old) planted across three different sites in Australia. They reported higher wood density in E. globulus clones at lower rainfall, lower productivity site (Parkham), compared to the wetter, higher productivity sites (West Ridgley): the wood from the wetter site had on average $11 \%$ lower wood density compared with the wood produced in the poor site.

Downes et al. (2014) thoroughly investigated this issue using a Eucalyptus globulus in Western Australia. They have evaluated the effects of fertilizer and plantation stocking on the wood properties in trees growing in three sites differing in annual rainfall $(620-1100 \mathrm{~mm})$, open-pan evaporation and soil water-holding capacity. According to the findings of Downes et al. (2014), the site with low annual rainfall, the lowest climate wetness index and soil water storage capacity and the slowest diameter growth, provided the trees with the highest mean wood density $\left(648 \mathrm{~kg} \cdot \mathrm{m}^{-3}\right)$ while trees growing in the site with the highest rainfall, had $10 \%$ lower mean wood density.

\section{Spatial variation of wood stiffness}

The patterns of variation in MOE and $\rho$ were similar when considering overall values: the radial variation in MOE was higher than those from botton to top of the trees. Modulus of elasticity strongly increased radially from 8,970 to $16,800 \mathrm{MPa}$ at $25 \%$ of the height. The increase was also high in the upper part of the trunk: $\sim 5626 \mathrm{MPa}$ and $\sim 3869 \mathrm{MPa}$ at $50 \%$ and $75 \%$ of the tree height, respectively. Similarly to the wood density, the variation in the tree top was low because these woods were produced recently, some months before harvesting. These findings are consistent with those of Downes et al. (2014) who reported that the modulus of elasticity radially increased from $55 \%$ to $174 \%$ in Eucalytus globulus wood, depending on the silvicultural treatments.

The spatial variation trends for MOE were different for those for $\rho$ when the tree growing site was taken into account in the analysis. Radial increase of MOE was significantly higher in trees grown in Sites 301 (20 degree slope and high wind speed) and 302 (higher slope degree) when compared to variation in trees from Site 303 (no slope).

At $25 \%$ of the tree height, the radial increase was $\sim 7500 \mathrm{MPa}(\sim 74 \%$, Table 3$)$ in the trees from Sites 301 and 302 while the wood stiffness increased $5760 \mathrm{MPa}(\sim 80 \%$, Table 3$)$ from pith to cambium in the site at $0^{\circ}$. However, there was no difference between sites in radial increase of wood stiffness of the base of the trunk. 
Variations in wind speed and terrain slope seems to induce changes in elastic modulus. The higher the terrain slope and wind speed in the field, the higher the elastic modulus of the produced wood. These effects are supposed to be similar and cumulative.

Figure 4

Figure 4 associated to Table 3 revealed that the radial increase in MOE is more pronounced at $25 \%$ of the tree height. We suppose that this high variation is caused by a shape effect. When a clamped beam with a conical shape is bending, the stress is maximum near the clamped end (depending on the real shape). Thus, the tree produces wood with maximum modulus of elasticity at this address to limit the deformation in this critical region.

The wind causes a cyclic bending the trunk and the outer portion of the trunk is more liable to tension or compression stress variations when the wind is stronger. This can explain why the clones growing at the Site 301 (20 degrees) produced the stiffer (and denser) outer wood (Figure 4B). We assume that the wind speed was the main factor affecting stiffness and causing high increase in wood rigidity towards the cambium. The inclination of $20^{\circ}$ also played a role in those variations but is a controlling factor of secondary importance.

Wood stiffness is related to wood density and microfibril angle (Evans and Ilic 2001) and wood stiffness increases as density increases and MFA decreases (Yang and Evans 2003). Thus, the knowledge about the factor driving spatial variation in modulus of elasticity can be potentially interesting for sawn timber producers.

\section{Spatial variation in microfibril angle}

MFA plays a central role in tree biomechanics. According to Barnett and Bonham (2004) high MFA in the centre of the tree, which were produced when the tree was a sapling, endow the wood with a low stiffness, enabling the sapling to bend in a high wind without breaking. As the tree enlarges, the trunk has to become stiffer to support the increasing weight of the trunk and crown. The lower MFA of the outer wood means that it has a higher stiffness to enable it to fulfil this role.

Here, the trends in MFA variation were inversely similar to those for wood density and stiffness. The microfibril angle of the secondary cell wall decreased, on average, by $\sim 4.4$ degrees from pith to bark at $25 \%$ of height. Considering the growing conditions, the radial decrease of MFA in the trees grown under high wind speed (Site 301, 20 degrees) was significantly higher at all relative tree heights, except at the base of the trunk.

The wind effect appears to be more evident for MFA variation. The wood of the clones planted at Site 301 have the highest MFA, but the trend is reversed with age and the clones present the lower MFA when they reach 5-6 years old. The radial decrease in MFA $\left(5.2^{\circ}\right)$ at $25 \%$ of the relative height of the trees grown on Site 301 was more than $30 \%$ above those of the trees from Sites 303 and 302. The trees growing on Site 301 produced the higher MFA values in the inner wood (Figure $5 \mathrm{~A}$ ) and the lower MFA values in the outer wood (Figure $5 \mathrm{~B}$ ). At the upper part of the trunk, the difference of radial decrease in MFA between sites was still higher and significant. This spatial variation trend was inversely observed for stiffness and could be attributed to the higher mean wind velocity of the site at $20^{\circ}$, at least partially.

Figure 5 
In the study presented by Wimmer et al. (2008), who have analyzed the wood of eight-year old Eucalyptus globulus clones growing in three sites in Australia, the wood of trees growing in the poor site (Parkham, a lower rainfall and productivity site) presented greater microfibril angles than those from the good site (West Ridgley, a wetter, higher productivity site).

Analyzing these results requires an important consideration: the aging of the meristematic cells that produces the cambium. At the base, the first growth ring is totally juvenile: meristem and cambium had similar age. On the other hand, in the outer ring of the trunk, the cambium was 6 years old while the cambium of the top of the tree was a few months old during the production of the outer wood. The cambial juvenility is frequently less pronounced in the top. These issues are discussed in Thibaut et al. (2001).

\section{Tension wood}

It is expected that Eucalyptus trees growing at sloped and/or windy sites produces a special wood called tension wood. This kind of wood is produce by the trees in reaction to an external load such as wind or to conteract an imbalance of the weight which is expected on sloped sites (Alméras and Fournier 2009). Tension wood is known to have peculiar composition and organization of the cell wall, especially a low lignin content and microfibril angle nearly parallel to the cell axis. Tension wood is also characterized in numerous species by a thicker fiber wall and fewer and smaller vessels (Jourez 2001) leading to a denser wood (Washusen et al. 2001). The higher density associated to low MFA make tension wood generally stiffer than normal wood (Clair et al. 2003).

Therefore, all parameters seem to indicate that the denser wood observed in our sampling may be due to the presence of tension wood. It is, however, interesting to notice that angiosperms growing under these conditions should present eccentric growth in the upper side of the leaning trunk or in the side receiving wind (Alméras and Fournier 2009). However, the discs studied here did not present eccentric pith. Another point to be mentioned is that darker ring-shaped zones were observed in a few disc samples cut from the three sites. These zones presented collapse after drying which is known to be often associated to tension wood (Washusen and Ilic 2001). One can macroscopically visualize the vessels in the "normal" zone, but in the collapsed zone and/or in the zone where tension wood occurs, it is not possible to see any pores (Figure 6). NIR spectra were not measured in these dark zones.

Figure 6

Unfortunately this behavior was observed in some samples a few years after the study had been carried out. The failure of this study was in not examining the likely tension wood formed in the trunks subjected to the action of wind or slope.

\section{CONCLUDING REMARKS}

This study established the spatial variation of basic density, stiffness and MFA along Eucalyptus trees. It was possible to compare the variations in wood traits among contrasting sites. The patterns of spatial variation in basic density, stiffness and microfibril angle along the Eucalyptus trunks indicates that wood variability in trunks is not negligible, even for six-yearold trees.

Patterns of spatial variation of wood traits have been reported in many studies. However, the effects of growing conditions on the wood variation are still a matter of debate. In this study, the 
higher the slope of the terrain, the greater the magnitude of radial variation in wood density, especially around $25 \%$ of height. The spatial variation of wood stiffness seems to be sensitive to variation in terrain slope and wind speed. The radial decrease in MFA was more pronounced at the site where the wind speed was high. There was no significant effect of growing conditions on the radial variation at the base and top of the tree for wood density, stiffness and MFA.

Considering the absolute values, the study revealed that clones produce significantly denser wood at the site where the wind speed was higher, the mean annual temperature is lower and the soil type is Inceptisol, both in the inner wood and in the outer sapwood. The trees growing on this site also produced the stiffer (and denser) outer wood and presented the higher MFA values in the inner wood and the lower MFA values in the outer sapwood. This behavior makes the trunks more flexible while thin, and stiffer when grown.

The spatial variation along the trunks presented here indicates that trees are able to adapt their wood to the changing environmental conditions in order to solve biomechanic constraints. Trees growing on sloping ground and under wind produce denser and stiffer wood, attributed to be tension wood. This ability of making wood with high tensile stress naturally provides to the tree an active control of the shape at the trunk base, where the loading forces are the highest (Thibaut et al. 2001).

\section{REFERENCES}

Alméras T, Fournier M (2009) Biomechanical design and long-term stability of trees: morphological and wood traits involved in the balance between weight increase and the gravitropic reaction. J Theoret Biol 256:370-381.

Alzate SBA, Tomazello Filho M, Piedade SMS (2005) Variação longitudinal da densidade básica da madeira de clones de Eucalyptus grandis Hill ex Maiden, E. saligna Sm. e E. grandis $\mathrm{x}$ urophylla. Scientia Forestalis 68: 87-95

ASTM - American Standards and Testing Methods (2002) D2395-02 - Standard test methods for specific gravity of wood and wood-based materials, West Conshohocken, PA, USA

Barnett JR, Bonham VA (2004) Cellulose microfibril angle in the cell wall of wood fibres. Biol Rev 79:461-472.

Bouvet JM, Bailleres H (1995) Expression of some growth and wood property traits among Eucalyptus urophylla $\mathrm{x}$ grandis clones in Congo. CRC for Temperate Hardwood Forestry IUFRO, Hobart. 1995. p.89-92.

Brancheriau L, Baillères H (2002) Natural vibration analysis of clear wooden beams: a theoretical review. Wood Sci Technol 36:347-365.

Chafe SC (1986) Radial variation of collapse, volumetric shrinkage, moisture content and density in Eucalyptus regnans F. Muell. Wood Science and Technology 20(3): 253-262

Clair B, Ruelle J, Thibaut T (2003) Relationship between growth stress, mechanical-physical properties and proportion of fibre with gelatinous layer in chestnut (Castanea sativa Mill.). Holzforschung 57:189-195. 
Cruz CR, Lima JT, Muniz GIB (2003) Variações dentro das árvores e entre clones das propriedades físicas e mecânicas da madeira de híbridos de Eucalyptus. Scientia Forestalis 64(1):33-47.

Downes G, Harwood C, Washusen R, Ebdon N, Evans R, White D, Dumbrell I (2014) Wood properties of Eucalyptus globulus at three sites in Western Australia: effects of fertilizer and plantation stocking. Australian Forestry 77(3-4):179-188.

Downes GM, Harwood CE, Wiedemann J, Ebdon N, Bond H, Meder R (2012) Radial variation in Kraft pulp yield and cellulose content in Eucalyptus globulus wood across three contrasting sites predicted by near infrared spectroscopy. Can J For Res 42:1577-1586.

Evans R, Ilic J (2001) Rapid prediction of wood stiffness from microfibril angle and density. For Prod J 51(3):53-57.

Evans R, Stringer S, Kibblewhite RP (2000) Variation of microfibril angle, density and fibre orientation in twenty-nine Eucalyptus nitens trees. Appita J 53:450-457.

Gonçalves JLM, Stape JL, Laclau JP, Smethurst P, Gava JL (2004) Silvicultural effects on the productivity and wood quality of eucalypt plantations. For Ecol Manag 193: 45-61.

Guilley E, Herve JC, Nepveu G (2004) The influence of site quality, silviculture and region on wood density mixed model in Quercus petraea Liebl. For Ecol Manag 189:111-121.

Hein PRG (2012) Estimating shrinkage, microfibril angle and density in Eucalyptus wood by near infrared spectroscopy. J Near Infrared Spectrosc 20(5):427-436.

Hein PRG, Brancheriau L (2011) Radial variation of microfibril angle and wood density and their relationships in 14-year-old Eucalyptus urophylla S.T. Blake wood. BioResources $6(3): 3352-3362$.

Hein PRG, Brancheriau L,Trugilho PF, Lima JT,Chaix G (2010) Resonance and near infrared spectroscopy for evaluating dynamic wood properties. J Near Infrared Spectrosc 18(6):443-454.

Hein PRG, Lima JT, Gril J, Rosado AM, Brancheriau L (2012) Resonance of structural timbers indicates the stiffness even of small specimens of Eucalyptus from plantations. Wood Sci Technol 46(4):621-635.

Jourez B, Riboux A, Leclercq A (2001) Anatomical characteristics of tension wood and opposite wood in young inclined stems of poplar (Populus euramericana CV “Ghoy"). IAWA J 22:133-157.

Kollmann FR, Côté WA (1968) Principles of Wood science and technology. Berlin: SpringerVerlag, 592p.

Lima JT, Breese MC, Cahalan CM (1999) Variation in compression strength parallel to the grain in Eucalyptus clones. Proceedings of the Fourth International Conference on the Development of Wood Science, Wood Technology and Forestry, Missenden Abbey, UK, 1416 July 1999 .

Lima JT, Breese MC, Cahalan CM (2004) Variation in microfibril angle in Eucalyptus clones. Holzforschung 58:160-166. 
Miranda I, Almeida MH, Pereira H (2001) Provenance and site variation of wood density in Eucalyptus globulus Labill. at harvest age and its relation to a non-destructive early assessment. For Ecol Manag 149:235-240.

Oliveira JTS, Silva JC (2003) Variação radial da retratibilidade e densidade básica da madeira de Eucalyptus saligna Sm. Revista Árvore 27(3): 381-385

Quilhó T, Pereira H (2001) Within and between-tree variation of bark content and wood density of Eucalyptus globulus in commercial plantations. IAWA Journal 22(3): 255-265

Raymond CA (2002) Genetics of Eucalyptus wood properties. Ann For Sci 59:525-531.

Thibaut B, Gril J, Fournier M (2001) Mechanics of wood and trees: some new highlights for an old story. ComptesRendus de l'Academie des Sciences Series IIB Mechanics. 329(9):701-716.

Thomas DS, Montagu KD, Conroy JP (2007) Temperature effects on wood anatomy, wood density, photosynthesis and biomass partitioning of Eucalyptus grandis seedlings. Tree Physiology 27:251-260.

Timoshenko S (1921) On the correction for shear of the differential equation for transverse vibrations of prismatic bars. Philosophical Magazine and Journal of Science XLI - Sixth Series:744-746.

Walker JCF, Butterfield BG (1995) The importance of microfibril angle for the processing industries. New Zealand Forestry, November:35-40.

Washusen R, Ades P, Evans R, Ilic J, Vinden P (2001) Relationships between density, shrinkage, extractives content and microfibril angle in tension wood from three provenances of 10-year-old Eucalyptus globulus Labill. Holzforschung 55:176-182.

Washusen R, Ilic J (2001) Relationship between tranvesrse shrinkage and tension wood from three provenances of Eucalyptus globulus Labill. Holz als Roh- und Werkstoff 59:85-93.

Wimmer R, Downes G, Evans R, French J (2008) Effects of site on fibre, kraft pulp and handsheet properties of Eucalyptus globulus. Ann For Sci 65(6):602.

Yamamoto H, Okuyama T,Yashida M (1993) Method of determining the mean microfibril angle of wood over a wide range by the improved Cave's method. Mokuzai Gakkaishi 39:118125 .

Yang, J.L.; Evans, R. 2003.Prediction of MOE of eucalypt wood from microfibril angle and density. Holz als Roh- und Werkstoff 61 (6):449-452.

Zhang S-B, Ferry SlikJW, Zhang J-L, Cao K-F (2011) Spatial patterns of wood traits in Chinaare controlled by phylogeny and the environment. Global Ecol Biogeograp 20:241-250.

Zobel B (1992) Silvicultural effects on wood properties. IPEF international, Piracicaba (2):3138. 


\section{LIST OF FIGURE AND CAPTIONS}

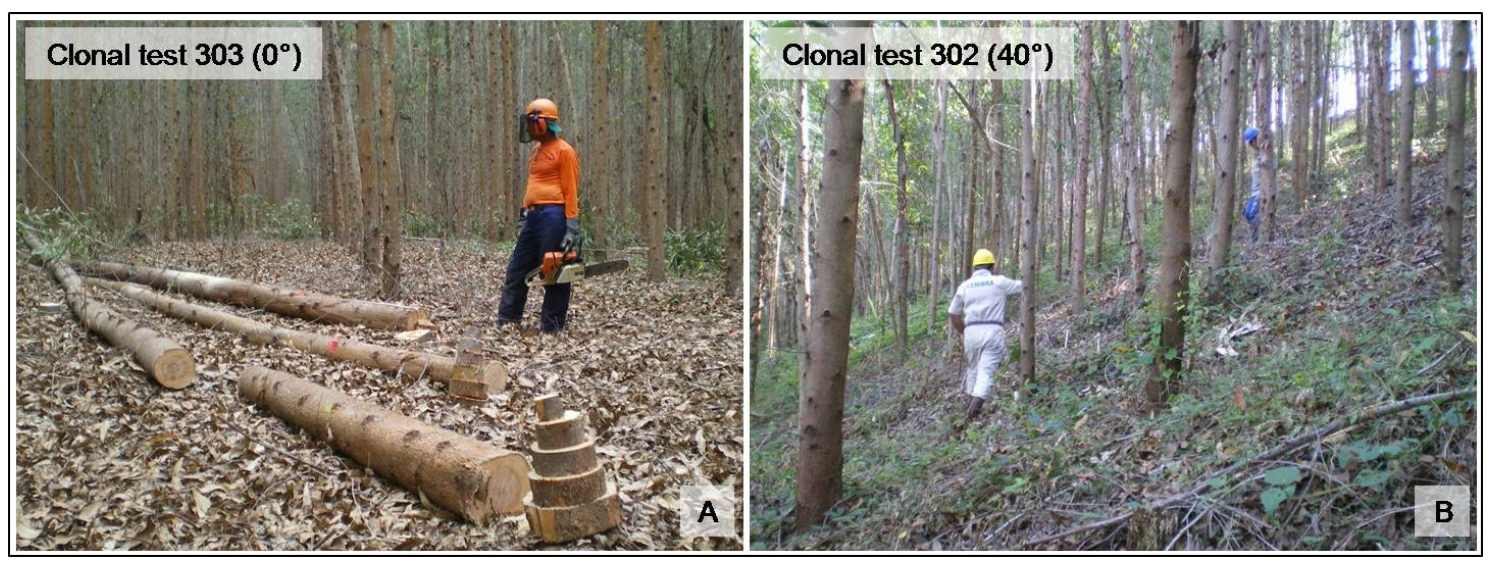

Fig 1 - Differences of growth conditions between clonal tests. The slope of clonal test 303 is zero (A) while the clonal test 302 has a $40^{\circ}$ inclination (B).

1) Sampling and measurements: 150 logs and specimens, cubic samples and radial sections

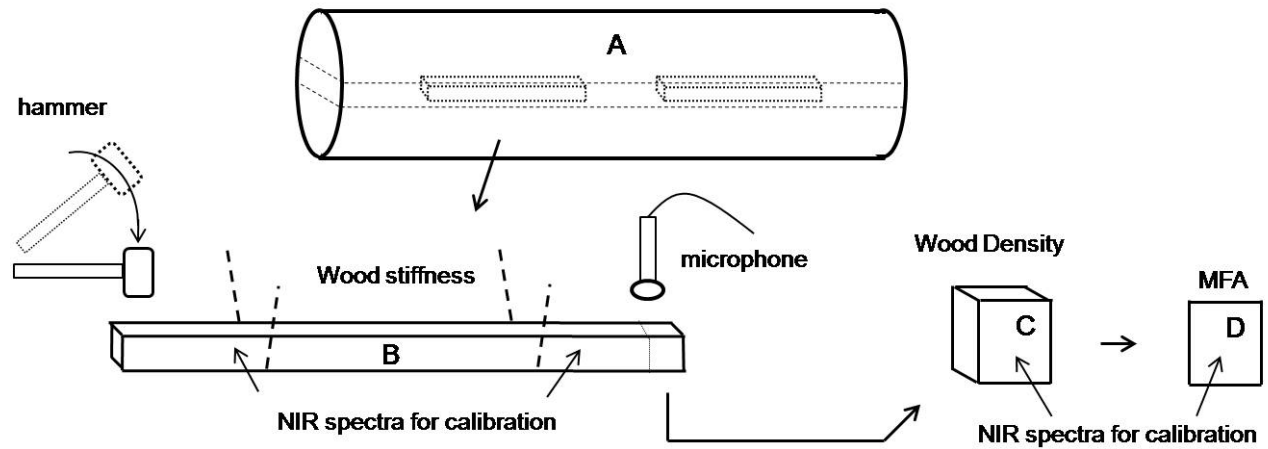

2) Estimating wood traits: measuring NIR spectra and predicting wood traits on radial positions of 750 discs (150 trees $\times 5$ discs ) of 30 mm thick using NIR-based models
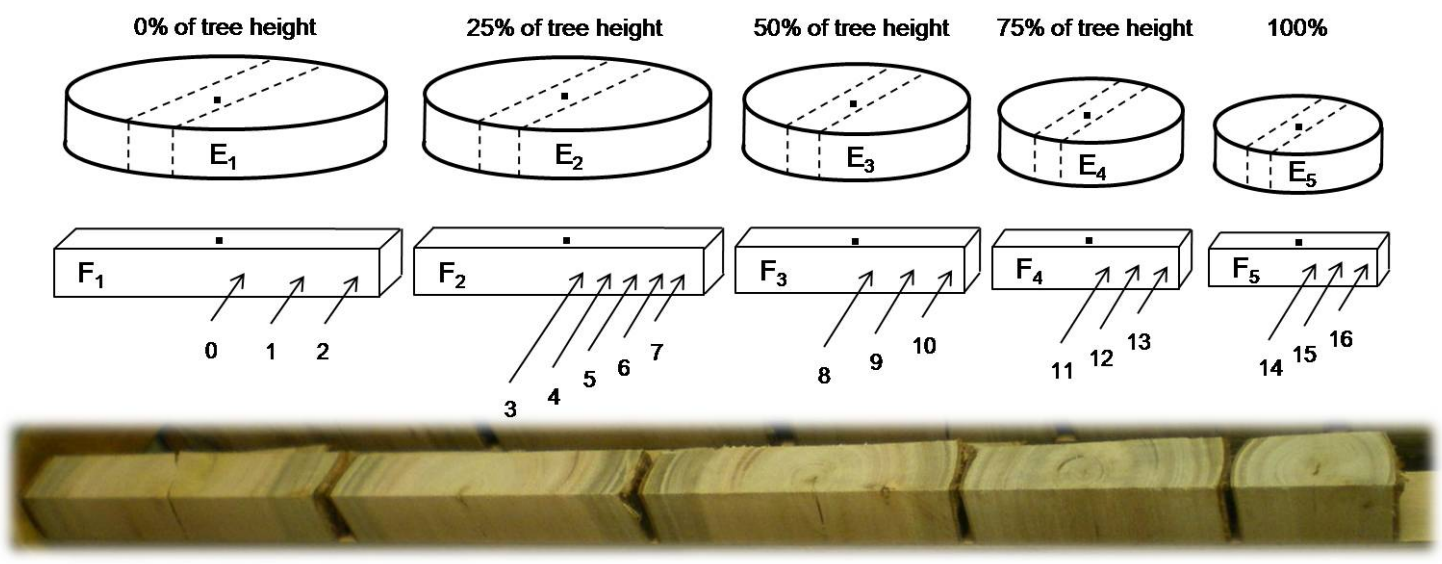

Fig 2 - Sample preparation procedure for wood characterization. Logs (A) were cut to produce wood specimens (B). After tests, specimens were cut to produce cubic samples (C) and then radial sections (D). Wood discs (E) and radial strips (F) cut from them for NIR spectra records and predictions in a range of radial and longitudinal positions. 


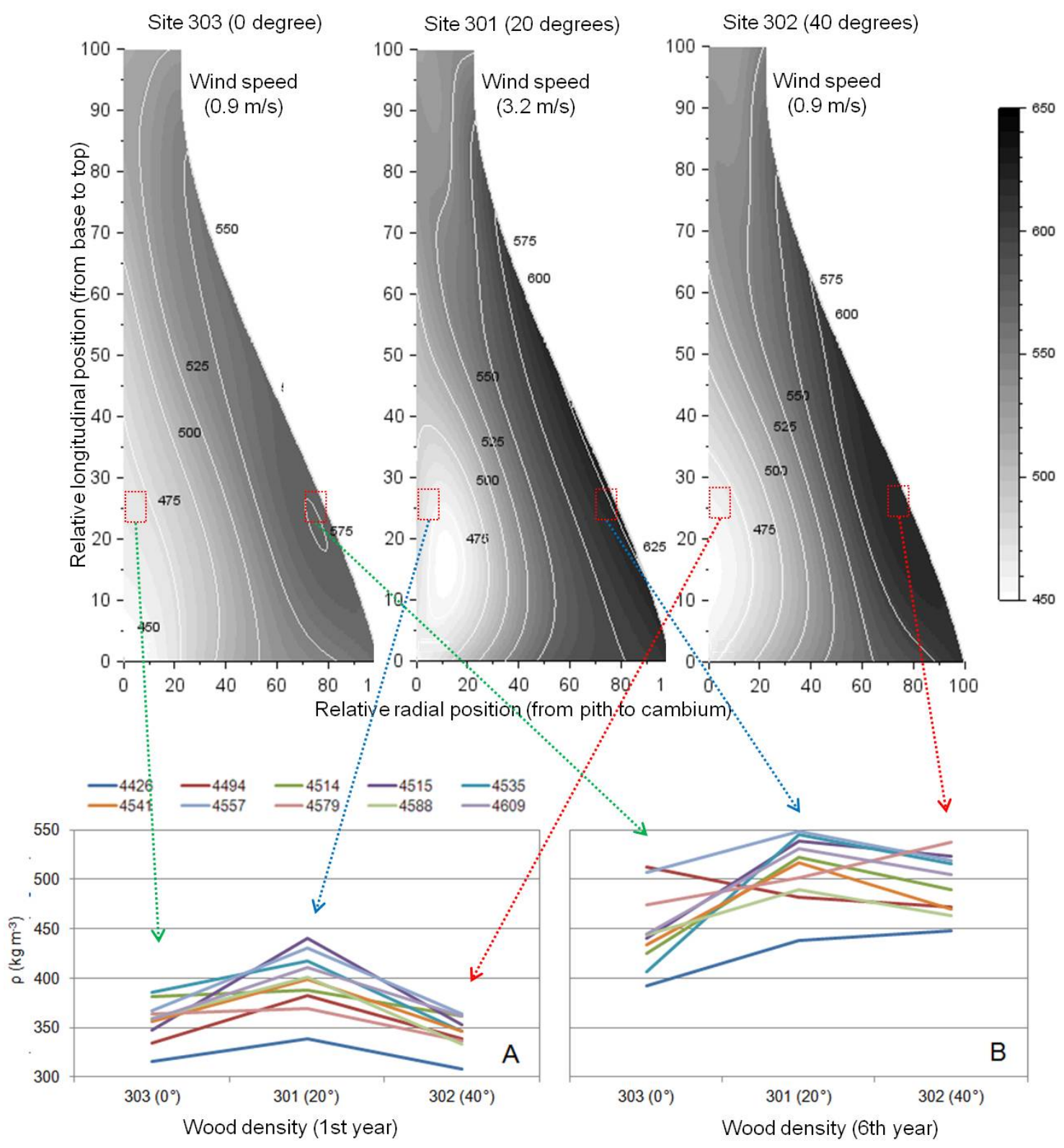

Fig 3 - Relative spatial variation of wood basic density $\left(\mathrm{kg} \mathrm{m}^{-3}\right)$ in Eucalyptus urophylla $\mathrm{x}$ E. grandis trees, highlighting the radial variation at $25 \%$ of the tree height and the radial variation of the wood density of clones. Top: mean value of all the studied clones. Bottom: Site interaction plot for each clone for the $25 \%$ position; A represent wood produced at one year while B the wood produced at 6 years. 


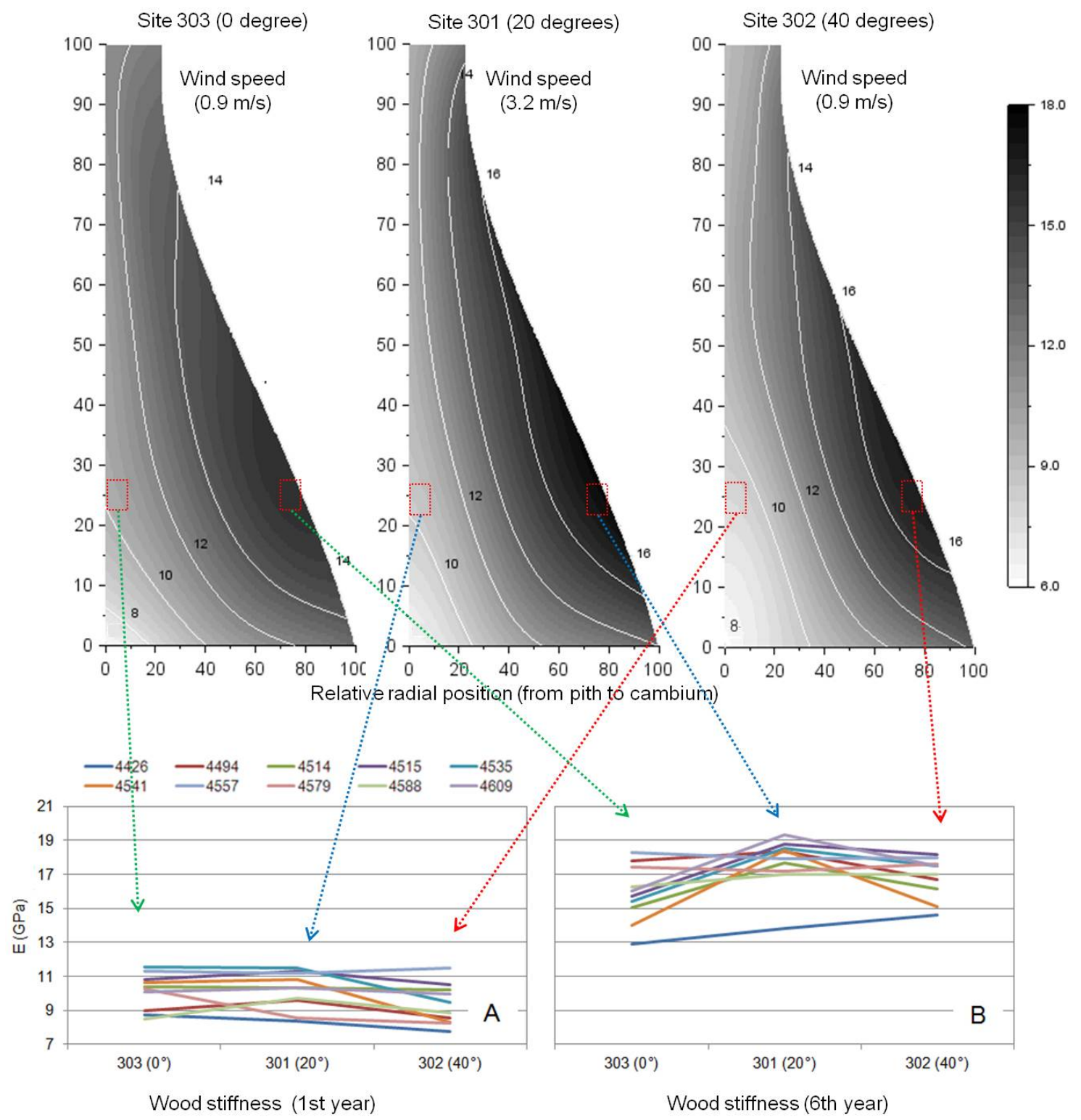

Fig 4 - Relative spatial variation of modulus of elasticity (MPa) in Eucalyptus urophylla x E. grandis trees, highlighting the radial variation at $25 \%$ of the tree height and the radial variation of the wood stiffness of clones at the clonal tests. Top: mean value of all the studied clones. Bottom: Site interaction plot for each clone for the $25 \%$ position; A represent wood produced at one year while B the wood produced at 6 years. 


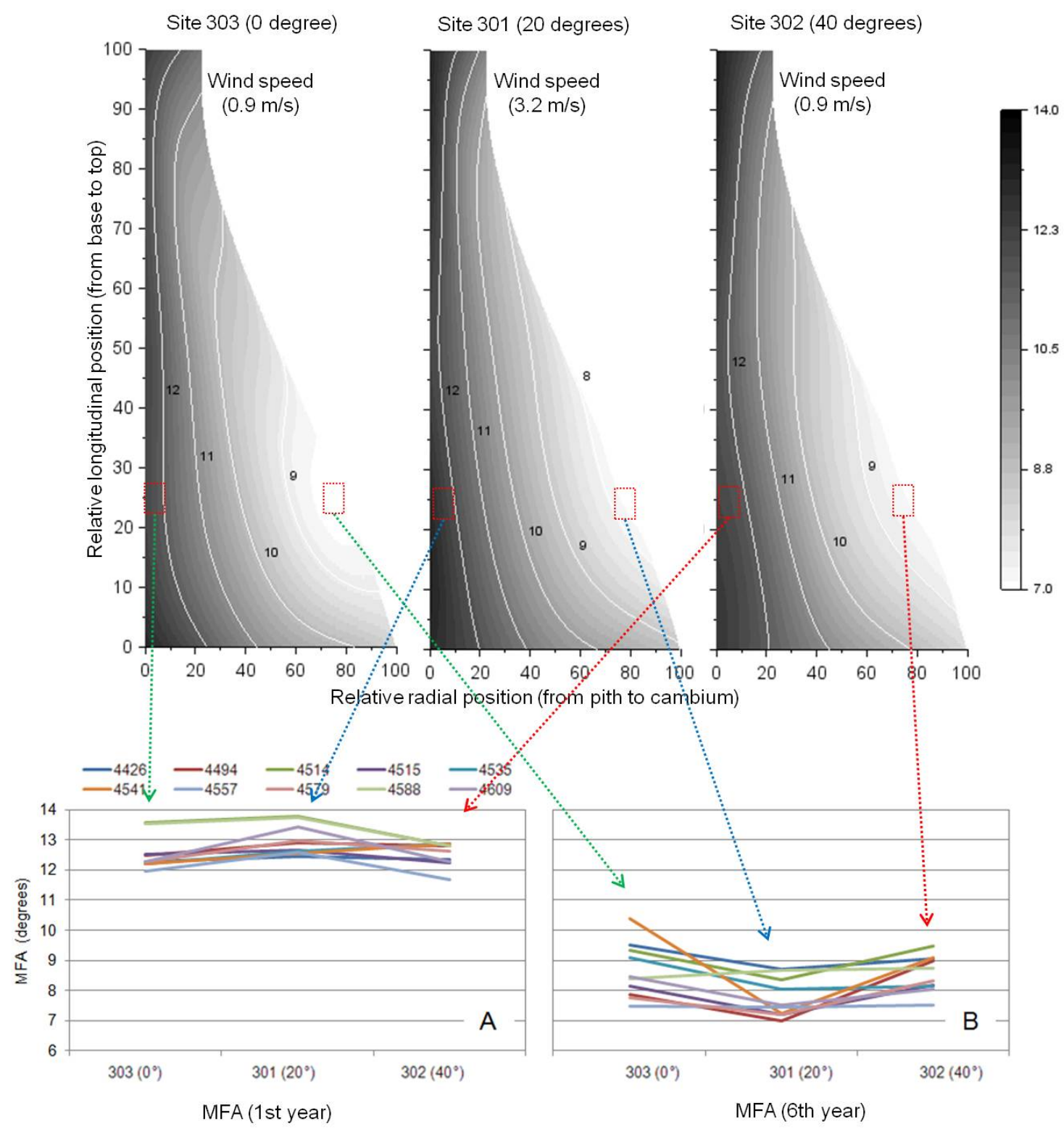

Fig 5 - Relative spatial variation of microfibril angle (degrees) in Eucalyptus urophyllax grandis trees, highlighting the radial variation at $25 \%$ of the tree height and the radial variation of the microfibril angle of clones in the clonal tests. Top: mean value of all the studied clones. Bottom: Site interaction plot for each clone for the $25 \%$ position;: A represent wood produced at one year while $\mathrm{B}$ the wood produced at 6 years. 


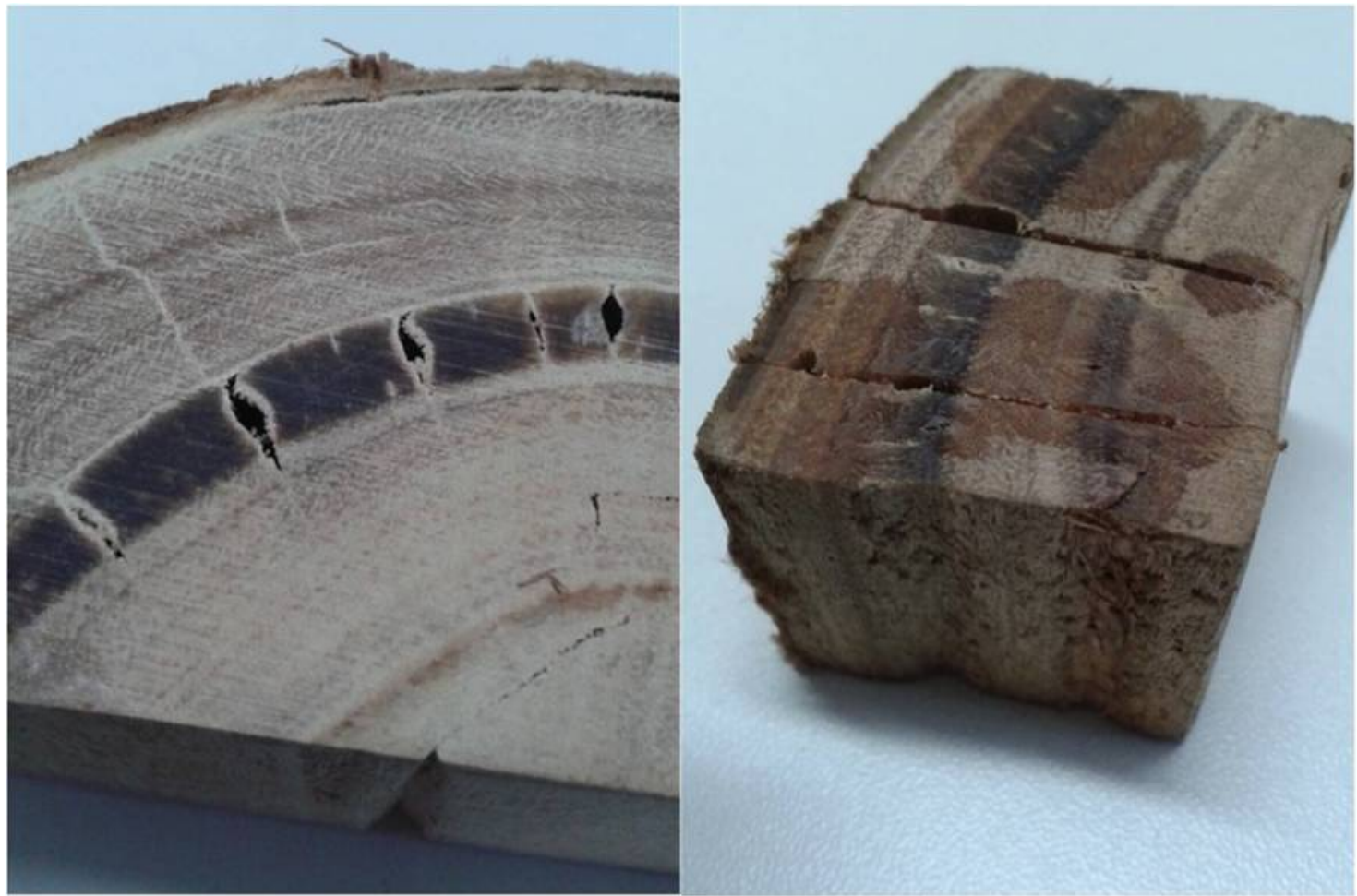

Fig 6 - Darker ring-shaped zones in wood Eucalyptus samples 


\section{LIST OF TABLES}

Table 1 - Description of the environmental information of the sites, including the slope of terrain, wind speed, mean temperature (Temp.) and mean relative humidity (RH), mean rainfall, circumference at breast height $(\mathrm{CBH})$, and mean height at 72 months. Values in parentheses are the coefficient of variation, in $\%$.

\begin{tabular}{|c|c|c|c|c|c|c|c|c|c|}
\hline Location & $\begin{array}{c}\text { Ground } \\
\text { slope }\end{array}$ & $\begin{array}{c}\text { Wind } \\
\text { speed } \\
(\mathrm{m} / \mathrm{s})\end{array}$ & Soil type & $\begin{array}{c}\text { Mean } \\
\text { Temp } \\
.\end{array}$ & $\begin{array}{c}\text { Mean } \\
\text { RH } \\
(\%)\end{array}$ & $\begin{array}{c}\text { Mean } \\
\text { rainfall } \\
(\mathrm{mm})\end{array}$ & $\begin{array}{c}\text { Hydric } \\
\text { deficit } \\
(\mathrm{mm})\end{array}$ & $\begin{array}{c}\text { Mean } \\
\text { CBH } \\
(\mathrm{cm})\end{array}$ & $\begin{array}{c}\text { Mean } \\
\text { Height } \\
(\mathrm{m})\end{array}$ \\
\hline $\begin{array}{c}\text { Brejo } \\
(303)\end{array}$ & $0^{\circ}$ & 0.9 & Oxisols & 24.5 & 70.5 & 1,230 & 299 & $67.3^{(17)}$ & $23.1^{(28)}$ \\
\hline $\begin{array}{c}\text { Guanhães } \\
(301)\end{array}$ & $20^{\circ}$ & 3.2 & Inceptisols & 21.3 & 65.7 & 1,182 & 150 & $60.8^{(10)}$ & $23.6^{(27)}$ \\
\hline $\begin{array}{c}\text { Coruja } \\
(302)\end{array}$ & $40^{\circ}$ & 0.9 & Entisols & 24.5 & 70.5 & 1,230 & 299 & $57.4^{(15)}$ & $20.4^{(28)}$ \\
\hline
\end{tabular}


Table 2 - NIR calibrations used for estimating wood basic density $\left(\rho, \mathrm{kg} \cdot \mathrm{m}^{-3}\right)$, modulus of elasticity (MOE, MPa) and microfibril angle (MFA, degrees) in 6-year-old Eucalyptus wood.

\begin{tabular}{cccccccc}
\hline Trait & Treat. & $\mathrm{R}^{2} \mathrm{p}$ & RMSEP & LV & Outliers & RPD & Reference \\
\hline$\rho$ & $\mathrm{snv}+1^{\mathrm{st}}$ der. & 0.80 & 22.9 & 3 & $2.6 \%$ & 2.32 & Hein $(2012)$ \\
MOE & $1^{\text {st }}$ der. & 0.81 & 1149 & 5 & $1.2 \%$ & 2.34 & Hein et al. (2010) \\
MFA & $\mathrm{snv} 1^{\mathrm{st}}$ der. & 0.75 & 1.31 & 5 & $6.6 \%$ & 2.10 & Hein $(2012)$ \\
\hline
\end{tabular}

Footnote: Treat: mathematical treatment of NIR spectra; snv: standard normal variate correction; $1^{\text {st }}$ der: first derivative transformation; $\mathrm{R}^{2} \mathrm{p}$ : coefficient of determination of prediction (test-set validation); RMSEP: the root mean standard error of prediction (test-set validation); LV: number of latent variables and RPD: ratio of performance to deviation 
Table 3 - Radial increase of wood properties (maximum value subtracted from the minimum value) according to the tree height (given in \% of commercial height) and growing conditions (see Table 1). Values in brackets are radial variation in percentage.

\begin{tabular}{ccccccc}
\hline \multirow{2}{*}{ Wood trait } & Site & \multicolumn{5}{c}{$\%$ of tree height } \\
\cline { 3 - 7 } & & $0 \%$ & $25 \%$ & $50 \%$ & $75 \%$ & $100 \%$ \\
\hline \multirow{5}{*}{$\rho\left(\mathrm{kg} . \mathrm{m}^{-3}\right)$} & $303\left(0^{\circ}\right)$ & $127.5^{\mathrm{a}}(29.1)$ & $104.4^{\mathrm{a}}(22.2)$ & $88.7^{\mathrm{a}}(18.4)$ & $46.7^{\mathrm{a}}(9.1)$ & $12.4^{\mathrm{a}}(2.4)$ \\
& $301\left(20^{\circ}\right)$ & $141.5^{\mathrm{a}}(29.9)$ & $\mathbf{1 3 2 . 9}^{\mathrm{b}}(26.8)$ & $98.1^{\mathrm{a}}(22.0)$ & $57.2^{\mathrm{a}}(10.6)$ & $17.6^{\mathrm{a}}(3.3)$ \\
& $302\left(40^{\circ}\right)$ & $144.4^{\mathrm{a}}(30.7)$ & $\mathbf{1 5 7 . 2}^{\mathrm{c}}(34.1)$ & $\mathbf{1 1 2 . 4}^{\mathrm{b}}(22.3)$ & $46.7^{\mathrm{a}}(8.7)$ & $24.7^{\mathrm{a}}(4.7)$ \\
& overall & 137.8 & 131.5 & 97.7 & 50.2 & 18.2 \\
\hline \multirow{6}{*}{ MOE $(\mathrm{MPa})$} & $303\left(0^{\circ}\right)$ & $6599^{\mathrm{a}}(100)$ & $5761^{\mathrm{b}}(57.0)$ & $4800^{\mathrm{b}}(45.1)$ & $2796^{\mathrm{b}}(24.7)$ & $1036^{\mathrm{b}}(9.0)$ \\
& $301\left(20^{\circ}\right)$ & $5908^{\mathrm{a}}(73)$ & $\mathbf{7 5 1 7}^{\mathrm{a}}(73.9)$ & $\mathbf{6 1 7 1}^{\mathrm{a}}(56.6)$ & $\mathbf{4 8 5 2}^{\mathrm{a}}(43.1)$ & $\mathbf{2 4 5 2}^{\mathrm{a}}(22.2)$ \\
& $302\left(40^{\circ}\right)$ & $6382^{\mathrm{a}}(81.5)$ & $\mathbf{7 5 0 2}^{\mathrm{a}}(80.4)$ & $\mathbf{5 9 0 6}^{\mathrm{a}}(56.1)$ & $\mathbf{3 9 5 9}^{\mathrm{a}}(37)$ & $\mathbf{2 0 8 3}^{\mathrm{a}}(20.0)$ \\
& overall & 6297 & 6927 & 5626 & 3869 & 1858 \\
\hline \multirow{3}{*}{ MFA $\left({ }^{\circ}\right)$} & $303\left(0^{\circ}\right)$ & $-3.64^{\mathrm{a}}(27.6)$ & $-3.88^{\mathrm{b}}(31)$ & $-3.5^{\mathrm{b}}(27.9)$ & $-2.28^{\mathrm{b}}(18.5)$ & $-1.26^{\mathrm{b}}(9.9)$ \\
& $301\left(20^{\circ}\right)$ & $-3.81^{\mathrm{a}}(29.5)$ & $\mathbf{- 5 . 2 2}^{\mathrm{a}}(40.3)$ & $-\mathbf{- 4 . 1 1}^{\mathrm{a}}(33.4)$ & $\mathbf{- 3 . 7 4}^{\mathrm{a}}(29.4)$ & $\mathbf{- 2 . 4 3}^{\mathrm{a}}(18.5)$ \\
& $302\left(40^{\circ}\right)$ & $-3.53^{\mathrm{a}}(27.5)$ & $-3.97^{\mathrm{b}}(31.7)$ & $-3.41^{\mathrm{b}}(27.7)$ & $-2.9^{\mathrm{b}}(22.5)$ & $-1.74^{\mathrm{b}}(13.1)$ \\
& overall & -3.66 & -4.36 & -3.67 & -2.97 & -1.81 \\
\hline
\end{tabular}

Footnote: The radial increase in absolute values for $\rho$ and MOE (or radial decrease for MFA) were compared among sites by the Tukey test at $\rho=0.01$ threshold (means followed by same letter do not significantly differ). Bold values highlight the higher radial variation. 